\title{
Expression of superantigens and the agr system in Staphylococcus epidermidis
}

\author{
Valéria Cataneli Pereira ${ }^{a, b, *}$, Luiza Pinheiro ${ }^{a}$, Adilson Oliveira ${ }^{a}$, Katheryne Benini Martins ${ }^{a}$, \\ Danilo Flávio Moraes Riboli ${ }^{a}$, Maria de Lourdes Ribeiro de Souza da Cunha ${ }^{a}$ \\ ${ }^{a}$ Laboratory of Bacteriology, Department of Microbiology and Immunology, Institute of Biosciences, UNESP - Univ. Estadual Paulista, CEP 18618-970, Botucatu, São \\ Paulo, Brazil \\ ${ }^{\mathrm{b}}$ Universidade do Oeste Paulista, CEP 19050-920, Presidente Prudente, São Paulo, Brazil
}

\section{A R T I C L E I N F O}

\section{Keywords:}

Coagulase-negative staphylococci

Staphylococcal enterotoxins

agr system

\begin{abstract}
A B S T R A C T
Infections with coagulase-negative staphylococci (CoNS) can involve the production of toxins such as superantigens, which contribute to tissue degradation and inflammatory immune responses. The accessory gene regulator (agr) quorum sensing system coordinates the expression of most $S$. aureus virulence factors. Therefore, the aim of this study was to investigate the expression of these superantigens and the presence of the agr locus in CoNS strains isolated from blood cultures. PCR was used to detect enterotoxin and agr genes and expression was analyzed by RT-PCR. Expression of the sea gene was observed in one $S$. epidermidis isolate andof sec-1 in two, seg and sei were expressed concomitantly in one isolate, and sei was expressed in another isolate. The agr group I was detected in S. epidermidis expressing the sea, seg and sei genes, whereas agr group II was detected in isolates expressing thesec-1 gene. The agr groups were only expressed in strains expressing thesec-1 gene. The results show that enterotoxin genes are highly frequent in CoNS isolated from clinical specimens and confirm the toxinproducing ability of these strains. The agr group II may be associated with enterotoxin C production by $S$. epidermidis, increasing the virulence of strains isolated from blood cultures and consequently the severity of sepsis caused by these organisms.
\end{abstract}

\section{Introduction}

Most species belonging to the genus Staphylococcus are coagulasenegative staphylococci (CoNS), i.e., they cannot produce the coagulase enzyme. Although CoNS are part of the human microbiota, they are considered opportunistic microorganisms because they take advantage of situations such as post-trauma tissue damage and the presence of foreign bodies to proliferate and spread to other tissues, developing a pathogenic behavior [1]. CoNS are the main cause of bacteremia in hospitals and their pathogenesis is complex, involving the production of a variety of virulence factors such as toxins $[2,3]$.

Staphylococcal toxins can contribute to tissue degradation and elicit anti-inflammatory immune responses [4]. Staphylococcal enterotoxins and toxic shock syndrome toxin 1 (TSST-1) are superantigens whose toxic effects can trigger the nonspecific proliferation of $\mathrm{T}$ cells through direct binding to major histocompatibility complex class II molecules and to the $\mathrm{V} \beta$ region of the $\mathrm{T}$ cell antigen receptor. Unlike normal antigen processing, they stimulate many $\mathrm{T}$ cells that overproduce cytokines such as interleukin 1 (IL-1), IL-2, interferon gamma (IFN- $\gamma$ ), and tumor necrosis factor alpha (TNF- $\alpha$ ) [5].
During infection, toxin production by staphylococci is a multi-stage process that is coordinated by a complex system of communication between bacterial cells. This mechanism, called quorum sensing, allows bacteria to share information about cell density and to establish a phenotypic reaction according to the growth stage of the culture $[6,7]$. Quorum sensing via the accessory gene regulator (agr) system is one of the main systems that coordinate staphylococcal virulence factors [8]. This system comprises promoters P2 and P3, which operate in opposite directions and produce transcripts RNAII and RNAIII, respectively. RNAIII is responsible for the gene transcription of a number of virulence factors, including extracellular toxins and enzymes and surface proteins [9]. The agr system is composed of four genes (agrA, agrB, agrC, and agrD) arranged in an operon. The products of these genes are proteins AgrA, AgrB, AgrC and AgrD, which are necessary for the function of the system. Proteins AgrB and AgrD combine to produce the autoinducing polypeptide (AIP), which is released into the extracellular medium. When the transmembrane protein AgrC detects AIP in the external environment, it phosphorylates AgrA that induces expression from P2 and P3. The final product of the agr locus is RNAIII, an mRNA that induces or inhibits toxin genes [7].

\footnotetext{
* Corresponding author. Laboratory of Bacteriology, Department of Microbiology and Immunology, Institute of Biosciences, UNESP - Univ. Estadual Paulista, CEP 18618-970, Botucatu, São Paulo, Brazil.

E-mail address: valeriacataneli@gmail.com (V.C. Pereira).
} 
Three polymorphisms of the agr locus (agr group I, group II and group III) have been described in Staphylococcus epidermidis [10]. These groups show variations in the agrB, agrC and agrD genes and thus in AIP and AgrC, with AIP binding to a specific receptor for each allelic group. When AIP of one allele group binds to the AgrC receptor of another group, it does not produce intrinsic factors and thereby behaves as an antagonist. AIP is the only agonist to its own allele group and bacteria of one agr group can therefore affect the regulation of accessory proteins of bacteria from another agr group [7].

In view of the increasing incidence of CoNS infection, studies on associated virulence factors are important to better understand the toxigenic potential of these microorganisms. Therefore, the present study evaluated the occurrence and expression of superantigens and the role of the agr system in the production of virulence factors by CoNS species isolated from blood cultures of patients hospitalized in the University Hospital of the Botucatu Medical School.

\section{Material and methods}

\subsection{Strains}

Three hundred CoNS strains isolated from blood cultures of patients admitted to the University Hospital of the Botucatu Medical School, State University of São Paulo (UNESP), were evaluated. The blood samples were collected between 1990 and 2009 and stored in the Culture Collection of the Department of Microbiology and Immunology, Biosciences Institute of Botucatu (UNESP). An average prevalence of $35 \%$, with a $5 \%$ error and $95 \%$ confidence interval, were defined as criteria for selection of each CoNS species.

The strains were isolated on blood agar plates as described by Koneman et al. [9] and suspected colonies were submitted to Gram staining. After confirmation of morphology and specific staining, catalase and coagulase tests were used to identify the isolates. Biochemical tests were performed for phenotypic identification of the CoNS species according to the simplified method of Cunha et al. [10]. Genotypic identification was carried out by PCR-based determination of internal transcribed spacer (ITS) regions according to Couto et al. [11].

\subsection{Extraction of DNA}

Total DNA was extracted from the CoNS strains cultured on blood agar, individually inoculated into BHI broth, and incubated for $24 \mathrm{~h}$ at $37{ }^{\circ} \mathrm{C}$. In brief, staphylococcal cells were digested with lysozyme $(10 \mathrm{mg} / \mathrm{mL})$ and proteinase $\mathrm{K}(20 \mathrm{mg} / \mathrm{mL})$. Next, $500 \mu \mathrm{L}$ of the extraction solution was added and the mixture was centrifuged at $5000 \times g$ for $1 \mathrm{~min}$. The supernatant was transferred to a GFX column and centrifuged at $5000 \times g$ for $1 \mathrm{~min}$. The fluid collected was discarded and $500 \mu \mathrm{L}$ of the extraction solution was again added to the column. After centrifugation and disposal of the collected fluid, $500 \mu \mathrm{L}$ of the washing solution was added and the column was centrifuged at $14,000 \mathrm{rpm}$ for $3 \mathrm{~min}$. The column was transferred to a 1.5-ml tube and $200 \mu \mathrm{L}$ Milli-Q water heated to $70^{\circ} \mathrm{Cwas}$ used for elution. The samples were centrifuged at $5000 \times g$ for $1 \mathrm{~min}$ and the GFX column was discarded. The extracted DNA was stored in a freezer at $4{ }^{\circ} \mathrm{C}$.

\subsection{Detection of enterotoxin and TSST-1 genes}

PCR was carried out in $0.5-\mathrm{ml}$ centrifuge tubes containing10 pmol of each primer (Table 2), $2.5 \mathrm{U}$ Taq DNA polymerase, $200 \mu \mathrm{mol} / \mathrm{L}$ deoxyribonucleotide triphosphates (dNTP), $20 \mathrm{mmol} / \mathrm{L}$ Tris- $\mathrm{HCl}, \mathrm{pH}$ $8.4,0.75 \mathrm{mmol} / \mathrm{L} \mathrm{MgCl}_{2}$, and $3 \mu \mathrm{L}$ of the sample in a final volume of $25 \mu \mathrm{L}$. A negative control in which the nucleic acid was replaced with water was included in all reactions. Amplification was carried out in an MJ Research PTC-100 thermocycler using the following parameters: one cycle at $94{ }^{\circ} \mathrm{C}$ for $4 \mathrm{~min}$, denaturation at $94{ }^{\circ} \mathrm{C}$ for $2 \mathrm{~min}$, primer annealing at $55{ }^{\circ} \mathrm{C}$ and extension at $72{ }^{\circ} \mathrm{C}$ for $1 \mathrm{~min} 30 \mathrm{~s}$, followed by a second cycle of denaturation at $94{ }^{\circ} \mathrm{C}$ for $2 \mathrm{~min}$, annealing at $53{ }^{\circ} \mathrm{C}$ and extension at $72{ }^{\circ} \mathrm{C}$ for $1 \mathrm{~min} 30 \mathrm{~s}$. In the third cycle, the annealing temperature was reduced to $51{ }^{\circ} \mathrm{C}$ and 37 cycles were carried out using the last parameters. After completing 40 cycles, the tubes were incubated at $72{ }^{\circ} \mathrm{C}$ for $7 \mathrm{~min}$ and then cooled to $4{ }^{\circ} \mathrm{C}$.

\subsection{Extraction of RNA and cDNA synthesis}

Total RNA was extracted using the Illustra RNA spin Mini kit according to manufacturer recommendations. After treatment with DNAse, the mRNA samples were converted into cDNA. For that purpose, $12 \mu \mathrm{L}$ mRNA treated with DNase was added to $1 \mu \mathrm{L}$ of random primer(75 ng/ $\mu \mathrm{L}), 6 \mu \mathrm{L}$ nuclease-free water, and $1 \mu \mathrm{L}$ dNTP $(200 \mu \mathrm{M})$. The mixture was heated for $5 \mathrm{~min}$ at $65^{\circ} \mathrm{C}$ for RNA denaturation and primer binding and $4 \mu \mathrm{L}$ reverse transcription buffer, $1 \mu \mathrm{L}$ dithiothreitol and $1 \mu \mathrm{L}$ SuperScript ${ }^{\mathrm{TM}}$ III $(200 \mathrm{U} / \mu \mathrm{L})$ were added. cDNA was synthesized in a PTC- 100 thermocycler using one cycles at $25{ }^{\circ} \mathrm{C}$ for $5 \mathrm{~min}$, $50{ }^{\circ} \mathrm{C}$ for $60 \mathrm{~min}$, and $70{ }^{\circ} \mathrm{C}$ for $15 \mathrm{~min}$, followed by cooling at $4{ }^{\circ} \mathrm{C}$. As internal control, the expression of 16S rRNA using 16S1 and 16S2 primers (Table 2) was analyzed, which correspond to gene regions that are conserved in staphylococci and specific to the genus. The cDNA obtained was amplified by PCR and the resulting products were visualized by electrophoresis.

\subsection{Determination of the agr group}

The CoNS strains that tested positive for superantigen mRNA by the reverse transcription polymerase chain reaction (RT-PCR) were subjected to agr group typing by PCR as described by Li et al. [12]. The reactions were performed with primers targeting agrA, agrB and agrC (Table 1).

\subsection{Staphylococcus epidermidis typing by PFGE}

The modified protocol of McDougal et al. [13] was used to determine the clonal profile of the $S$. epidermidis spp. isolates. The strains were inoculated into BHI broth and incubated for $24 \mathrm{~h}$ at $37{ }^{\circ} \mathrm{C}$. The isolates were centrifuged in microtubes at $15,294 \times g$ for $1 \mathrm{~min}$. The supernatant was discarded and $300 \mu \mathrm{LTE}$ solution (10 mM Tris, $1 \mathrm{mM}$ EDTA, pH 8.0) was added. The strains were incubated in a water bath for $10 \mathrm{~min}$ at $37^{\circ} \mathrm{C}$. The cells were lysed by adding $5 \mu \mathrm{L}$ lysostaphin and vortexed, and $300 \mu \mathrm{L}$ of $1.8 \%$ low-melt agarose was added at $37{ }^{\circ} \mathrm{C}$. Plugs were prepared from the strains and the agarose was allowed to solidify. The plugs were then transferred to a 24-well plate containing $2 \mathrm{~mL}$ EC solution ( $6 \mathrm{mM}$ Tris- $\mathrm{HCl}, 1 \mathrm{M} \mathrm{NaCl}, 100 \mathrm{mM}$ EDTA, 0.5\% Brij$58,0.2 \%$ sodium deoxycholate, $0.5 \%$ sodium lauroyl sarcosinate) and incubated for $4 \mathrm{~h}$ at $37^{\circ} \mathrm{C}$. The EC solution was removed and the plugs were washed four times in $2 \mathrm{~mL}$ TE solution for $30 \mathrm{~min}$ at $21^{\circ} \mathrm{C}$.

One-third of the plug and $2 \mu \mathrm{L}$ SmaI were used for the restriction of genomic DNA. For restriction, buffer without the enzyme (45 $\mu \mathrm{L}$ Milli-Q water and $5 \mu \mathrm{L}$ of the enzyme buffer) was added to a 96 -well plate and the plate was stored in a refrigerator for $30 \mathrm{~min}$ at $4{ }^{\circ} \mathrm{C}$. The buffer without the enzyme was removed and buffer containing the enzyme (43 $\mu \mathrm{L}$ Milli-Q water, $5 \mu \mathrm{L}$ enzyme buffer, and $2 \mu \mathrm{L}$ of the enzyme) was added. The plate was incubated in an oven for $6 \mathrm{~min}$ at $37{ }^{\circ} \mathrm{C}$. Electrophoresis was carried out in a CHEF-DR III System using 1\% agarose gel prepared in $0.5 \mathrm{M}$ TBE $(0.1 \mathrm{M}$ Tris, $0.08 \mathrm{M}$ boric acid, $1 \mathrm{mM}$ EDTA) under the following conditions: pulse times of 5-40 s for $21 \mathrm{~h}$ on a linear ramp; $6 \mathrm{~V} / \mathrm{cm}$; angle of $120^{\circ} ; 14{ }^{\circ} \mathrm{C}$; $0.5 \mathrm{M}$ TBE as running buffer. The Lambda Ladder PFG Marker was used as a molecular marker. The gels were stained with GelRed $(400 \mathrm{~mL}$ distilled water and $30 \mu \mathrm{L}$ GelRed) for $1 \mathrm{~h}$ and photographed under UV transillumination.

The BioNumerics 6.1 software was used for analysis of similarity, calculation of the Dice correlation coefficient, and construction of the dendrogram by the UPGMA method. Band position tolerance and optimization were set at 1.25 and $0.5 \%$, respectively. A similarity 
Table 1

Primers used for PCR detection of staphylococcal enterotoxin genes, agr locus and 16S and 23S genes.

\begin{tabular}{|c|c|c|c|}
\hline Primer & 5' to 3' nucleotide sequence & Size (bp) & Product \\
\hline sea1 & TTGGAAACGGTTAAAACGAA & 123 & Enterotoxin A \\
\hline sea2 & GAACCTTCССАTCAAAAACA & & \\
\hline seb1 & TCGCATCAAACTGACAAACG & 478 & Enterotoxin B \\
\hline seb2 & GCAGGTACTCTATAAGTGCC & & \\
\hline $\sec -11$ & GACATAAAAGCTAGGAATTT & 257 & Enterotoxin C \\
\hline $\sec -12$ & AAATCGGATTAACATTATCC & & \\
\hline sed1 & CTAGTTTGGTAATATCTCCT & 317 & Enterotoxin D \\
\hline sed2 & TAATGCTATATCTTATAGGG & & \\
\hline see1 & CAAAGAAATGCTTTAAGCAATCTTAGGCCAC & 482 & Enterotoxin E \\
\hline see2 & CTTACCGCCAAAGCTG & & \\
\hline seg1 & AATTATGTGAATGCTCAACCCGATC & 642 & Enterotoxin G \\
\hline seg2 & AAACTTATATGGAACAAAAGGTACTAGTTC & & \\
\hline seh1 & CAATCACATCATATGCGAAAGCAG & 375 & Enterotoxin $\mathrm{H}$ \\
\hline seh2 & CATCTACCCAAACATTAGCACC & & \\
\hline sei1 & CTCAAGGTGATATTGGTGTAGG & 576 & Enterotoxin I \\
\hline sei2 & AAAAAACTTACAGGCAGTCCATCTC & & \\
\hline tsst2 & TTTCCAATAACCACCCGTTT & & \\
\hline agrA1 & GCTGCAACCAAGAAACAACC & 1022 & agrI, II, III \\
\hline agrA2 & CGTGTATTCATAATATGCTTCGATT & & \\
\hline $\operatorname{agrB1}$ & TATGCAAGCCAAGCACTTGT & 453 & agrIII \\
\hline agrB2 & GTGCGAAAGCCGATAACAAT & & \\
\hline agrC1 & CCTTGGCTAGTACTACACCTTC & 615 & agrII \\
\hline $\operatorname{agrC2}$ & GTGCTTGGCTTGCATAAACA & & \\
\hline G1 & GAAGTCGTAACAAGG & & $16 S$ \\
\hline$L 1$ & CAAGGCATCCACCGT & - & $23 S$ \\
\hline
\end{tabular}

References: Jarraud et al.[27], Li et al. [12], and Couto et al. [11].

coefficient of $80 \%$ was chosen for the definition of clusters.

The following international clones, kindly provided by Dr. Antonio Carlos Campos Pignatari, Laboratório Especial de Microbiologia Clínica, Disciplina de Infectologia, Universidade Federal de São Paulo/ Escola Paulista de Medicina, and by Dr. Agnes Marie Sá Figueiredo, Universidade Federal do Rio de Janeiro, Instituto de Microbiologia Prof. Paulo de Góes, Brazil, were used as controls: USA800 (SCCmec IVa), JCSC 1968/CA05 (SCCmec IVa), JCSC 978/8/6-3P (SCCmec IVb), MR108 (SCCmec IVc), JCSC 4469 (SCCmec IVd), WB72/USA300 (SCCmec IV), USA400 (SCCmec IV), USA500 (SCCmec IV), OSPC (SCCmec IV), HAR24/EMRSA 15 (SCCmec IV), HU25 (SCCmec IIIa), 85/ 2082 (SCCmec III), and ANS 46 (SCCmec III).

\section{Results}

\subsection{Species identification}

The biochemical method for CoNS identification detected 223 (74.3\%) S. epidermidis, 27 (9.0\%) S. haemolyticus, 22 (7.3\%) S. hominis, $14(4.7 \%)$ S. warneri, 9 (3.0\%) S. lugdunensis, and 5 (1.7\%) S. capitis. The molecular method (ITS-PCR)identified 223 (74.3\%) S. epidermidis,
29 (9.7\%) S. haemolyticus, 23 (7.7\%) S. hominis, 11 (3.7\%) S. warneri, 9 (3.0\%) S. lugdunensis, and 5 (1.7\%) S. capitis. The agreement between methods was $98 \%$.

\subsection{Detection and expression of enterotoxin genes}

TSST-1 and enterotoxin genes were analyzed in the 300 CoNS isolates and $90.7 \%$ carried at least one of the genes. The sea gene was detected in 172 isolates (57.3\%), seb in 70 (23.3\%), sec-1 in 105 (35.0\%), sed in 7 (2.3\%), see in 8 (2.7\%), seg in $188(62.7 \%)$, seh in 39 (13.0\%), sei in 200 (66.7\%), and tst in 15 (5.0\%) (Table 2; Fig. 1).

The isolates that were positive for superantigen genes were subjected to RT-PCR for mRNA detection. Five $S$. epidermidis isolates were positive for enterotoxin mRNA ( 1 for sea, 1 for sei, 2 for sec-1, and 1 for both seg and sei).

\subsection{Detection and expression of the agr locus}

Agr groups I, II and III were studied in all S. epidermidis strains and their expression was analyzed in those producing enterotoxins. Of the 223 S. epidermidis studied, 143 (64.1\%) carried agr group I, 53 (23.7\%)

Table 2

Determination of enterotoxin and TSST-1 genes in coagulase-negative staphylococci isolated from blood cultures.

\begin{tabular}{|c|c|c|c|c|c|c|c|c|c|c|c|c|c|}
\hline \multirow[t]{2}{*}{ Gene $(\mathrm{N})$} & & \multicolumn{2}{|c|}{$\begin{array}{l}\text { S. epidermidis } \\
(223)\end{array}$} & \multicolumn{2}{|c|}{$\begin{array}{l}\text { S. haemolyticus } \\
\text { (29) }\end{array}$} & \multicolumn{2}{|c|}{$\begin{array}{l}\text { S. hominis } \\
\text { (23) }\end{array}$} & \multicolumn{2}{|c|}{$\begin{array}{l}\text { S. warneri } \\
(11)\end{array}$} & \multicolumn{2}{|c|}{$\begin{array}{l}\text { S. lugdunensis } \\
\text { (9) }\end{array}$} & \multicolumn{2}{|c|}{$\begin{array}{l}\text { S. capitis } \\
\text { (5) }\end{array}$} \\
\hline & & $\mathrm{N}$ & $\%$ & $\mathrm{~N}$ & $\%$ & $\mathrm{~N}$ & $\%$ & $\mathrm{~N}$ & $\%$ & $\mathrm{~N}$ & $\%$ & $\mathrm{~N}$ & $\%$ \\
\hline sea & (172) & 120 & 69.8 & 22 & 12.8 & 17 & 9.9 & 7 & 4.1 & 2 & 1.2 & 4 & 2.3 \\
\hline$s e b$ & (70) & 45 & 64.3 & 11 & 15.7 & 10 & 14.3 & 4 & 5.7 & 0 & 0 & 0 & 0 \\
\hline $\sec -1$ & (105) & 73 & 69.5 & 9 & 8.6 & 11 & 10.5 & 4 & 3.8 & 6 & 5.7 & 2 & 1.9 \\
\hline sed & (7) & 5 & 71.4 & 1 & 14.3 & 0 & 0 & 1 & 14,3 & 0 & 0 & 0 & 0 \\
\hline see & (8) & 4 & 50.0 & 2 & 25.0 & 1 & 12.5 & 1 & 12.5 & 0 & 0 & 0 & 0 \\
\hline seg & (188) & 131 & 69.7 & 22 & 11.7 & 19 & 10.1 & 7 & 3.7 & 4 & 2.1 & 5 & 2.7 \\
\hline seh & (39) & 24 & 61.5 & 7 & 17.9 & 5 & 12.8 & 1 & 2.6 & 2 & 5.1 & 0 & 0 \\
\hline sei & (200) & 144 & 72.0 & 18 & 9.0 & 20 & 10.0 & 7 & 3.5 & 7 & 3.5 & 4 & 2.0 \\
\hline tst & (15) & 11 & 73.3 & 1 & 6.7 & 1 & 6.7 & 0 & 0 & 1 & 6.7 & 1 & 6.7 \\
\hline
\end{tabular}

$\mathrm{N}$ : number of isolates. 


\begin{tabular}{|c|c|c|c|c|c|c|c|c|c|}
\hline sea & 172 & & & & & & & & \\
\hline$s e b$ & 50 & 70 & & & & & & & \\
\hline sec-1 & 62 & 27 & 105 & & & & & & \\
\hline sed & 7 & 3 & 2 & 7 & & & & & \\
\hline see & 7 & 2 & 2 & 0 & 8 & & & & \\
\hline seg & 134 & 59 & 69 & 6 & 6 & 146 & & & \\
\hline seh & 28 & 11 & 13 & 0 & 0 & 24 & 39 & & \\
\hline sei & 134 & 54 & 71 & 6 & 6 & 122 & 32 & 200 & \\
\hline \multirow[t]{2}{*}{$t s t$} & 5 & 0 & 10 & 0 & 0 & 2 & 2 & 9 & 15 \\
\hline & sea & seb & sec-1 & sed & see & seg & seh & sei & $t s t$ \\
\hline
\end{tabular}

Fig. 1. Combinations of staphylococcal enterotoxin and TSST-1 genes detected in CoNS strains isolated from blood cultures. The shaded squares indicate the total number of genes detected in the isolates.

agr group II, and 4 (1.8\%) agr group III. The agr locus was not identified in $23(10.3 \%)$ of the $S$. epidermidis isolates analyzed.

The $S$. epidermidis isolates expressing sea, sec-1 and sei carried agr group I and those expressing sec-1 carried agr group II. Of the $5 \mathrm{~S}$. epidermidis isolates expressing enterotoxin mRNA, only 2 expressed agr group II.

\subsection{Staphylococcus epidermidis typing by PFGE}

The similarity rate between the $S$. epidermidis isolates that expressed the enterotoxin genes was less than $80 \%$, which is the thre shold value for clustering. Therefore, the $S$. epidermidis isolates studied did not exhibit a clonal profile (Fig. 2).

\section{Discussion}

Coagulase-negative staphylococci are the main microorganisms isolated from clinical materials and the primary cause of bacteremia in hospitals, especially in immunosuppressed patients. The ability of these bacteria to colonize the skin and to spread through the body during infections is due to the production of virulence factors such as enterotoxins. The present study investigated 300 CoNS isolated from blood cultures of patients seen at the University Hospital of Botucatu. The isolates were collected over a period of 20 years to study staphylococcal superantigen genes, the expression of virulence factors, and detection of the agr locus.

Staphylococcus epidermidis was the most frequent species detected, accounting for $74.3 \%$ of all CoNS isolated. Despite their lower prevalence, the other species isolated are also of clinical importance since they can cause serious infections. A number of studies have shown that S. epidermidis is isolated from 74 to $92 \%$ of patients with nosocomial infections [14] and is the main species isolated from infections, particularly those originating from invasive procedures such as implantation of peripheral and central catheters [15]. Similar to our findings, other studies identified $S$. haemolyticus as the second most common CoNS species isolated from blood cultures, which can cause different infections such as sepsis, peritonitis, otitis, and urinary infection [16]. Staphylococcus hominis has been identified in cases of bacteremia [17] and $S$. warneri, $S$. capitis and $S$. lugdunensis have been associated with serious infections such as endocarditis [18-20].

Among the CoNS strains studied, 90.7\% exhibited enterotoxin genes (sea to sei) or TSST-1 (tst). Staphylococcus epidermidis carried the highest proportion of these genes, followed by $S$. haemolyticus and $S$. hominis. The higher frequency of superantigen genes in S. epidermidis supports the importance of this species, which has been implicated in the etiology of serious infections. In addition to being the main member of the human microbiota, the selective pressure in the hospital environment and use of antimicrobials and disinfectants may favor the persistence of more resistant and virulent strains. Cunha et al. [21] investigated the presence of enterotoxin A and D and TSST-1 genes in Staphylococcus strains isolated from clinical samples of newborns seen at the same hospital as the present study by PCR and found that $40 \%$ of the CoNS isolates were positive for at least one of the genes. The authors also observed that $32.2 \%$ of the same CoNS isolates carried at least one of the following genes: see, seg, seh, and sei [22].

Among the classical enterotoxin genes (sea to see), sea was the most frequent and was also expressed at the mRNA level in one of the $S$. epidermidis isolates. Calsolari et al. [23] detected classical enterotoxin genes in 49 of 90 CoNS strains and sea was identified in $18.6 \%$. In the present study, sea was detected along with other genes in a number of combinations. The sea gene is carried on a prophage [24], facilitating its dispersal among Staphylococcus strains. Its product, enterotoxin A, is one of the main toxins associated with food poisoning, exhibiting toxic effects at low levels [25].

The sec-1 was the second most frequent classical enterotoxin gene and was detected by RT-PCR in two S. epidermidis isolates. Sec is a chromosomal gene located on pathogenicity islands. Its three subtypes (sec-1, sec-2 and sec-3) are classified according to their specific antigens

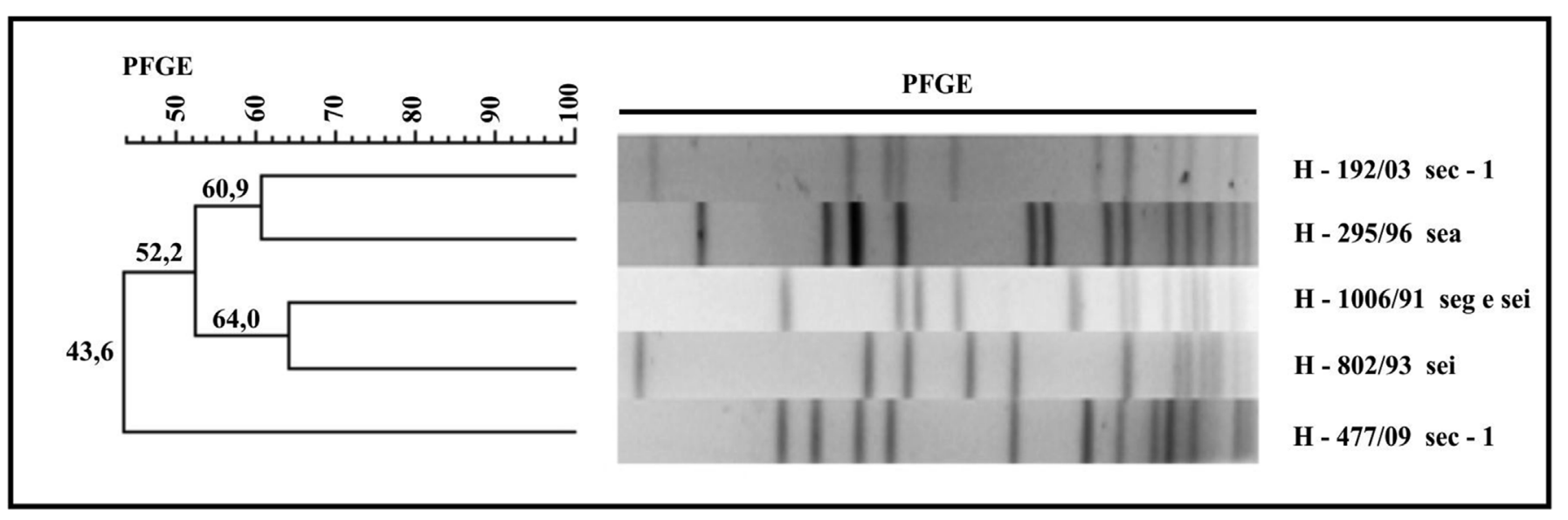

Fig. 2. Determination of the clonal profileof enterotoxin-producing Staphylococcus epidermidis strains isolated from blood cultures. 
and the respective host. Some studies suggest that the heterogeneity of enterotoxin $C$ is related to the selection of sec sequences, which can enhance staphylococcal survival in the corresponding hosts $[25,26]$.

The most frequent staphylococcal enterotoxin genes were seg and $s e i$, which were identified in $62.7 \%$ and $66.7 \%$ of the CoNS isolates, respectively. These genes showed a high correlation and were associated with other genes in several combinations. Vasconcelos et al. [22] found lower proportions of seg and sei in CoNS strains $12.2 \%$ and $22.2 \%$, respectively) and described their co-occurrence. Jarraud et al. [27] reported the co-occurrence of seg and sei, which are arranged in tandem orientation in an enterotoxin gene cluster (egc), and their expression along with sem, sen and seo. Varshney et al. [28] detected seg and sei (44\% and 46\%, respectively) in S. aureus isolated from blood cultures and found the complete gene cluster in $10 \%$ of the strains. The seg and sei mRNAs were simultaneously detected in one $S$. epidermidis isolate and sei mRNA alone in another isolate. The other enterotoxin genes (seb, sed, see, seh, and tst) were detected at lower levels, but their expression was not confirmed.

The agr locus was investigated in the $S$. epidermidis isolates and three groups were identified. Corroborating earlier studies [12,29], there was a predominance of agr group I, followed by agr group II and group III. According to Li et al. [12], polymorphisms in the agr locus may be associated with pathogenicity. In this respect, agr group I is associated with pathogenic $S$. epidermidis isolated from blood cultures and catheters, while agr group II and group III are found in S. epidermidis isolated from healthy individuals [29]. Some authors suggest that variations in the agr locus were selected during evolution and represent a fundamental aspect of strain divergence that permits adaptation to the microenvironment of specific infection sites $[6,29]$.

The agr group I and group II were found in the strains that expressed the enterotoxin genes. The isolate expressing sea carried agr group I, but mRNA was not transcribed from this locus. Enterotoxin A is produced at the beginning of the exponential phase of bacterial proliferation and the expression of its gene is not regulated by agr, in contrast to enterotoxins B, C and D that depend on the agr system for total expression [30-34]. The strains expressing seg and sei also carried agr group I, but mRNA was not transcribed from this locus. The agr group II was detected in the two strains expressing sec-1 which were positive for mRNA, suggesting that this locus is associated with the expression of the enterotoxin $\mathrm{C}$ gene in S. epidermidis. Regassa et al. [31] suggested the agr locus to be one of the determinants of maximum sec expression in $S$. aureus and found mRNA levels to be 2 to 3 times lower in agr-negative strains. Staphylococcus epidermidis is a versatile microorganism that can undergo rapid metabolic adaptations through sophisticated gene regulation mechanisms to cope with external conditions, to escape the host immune response, and to communicate with surrounding cells [32].

The $S$. epidermidis strains that expressed the enterotoxin genes were subjected to PFGE to determine their clonal profile. However, the results showed no similarities, indicating diversity among strains isolated in the same hospital that express toxin genes. The detection of $S$. epidermidis strains from blood cultures is important because they can produce superantigens similar to those produced by $S$. aureus, aggravating infections. Studies have suggested enterotoxins to play a role in the development of septic arthritis, in which the activation of an exaggerated inflammatory response triggers the release of significant amounts of cytokines that activate a large number of $\mathrm{T}$ cells and macrophages, causing tissue damage [33,34]. Enterotoxins have also been described to be involved in sepsis, osteomyelitis, and sinusitis [35]. Thus, attention must be paid to the bacteria that produce these toxins and to potential pathogen dissemination in the hospital environment.

A small number of isolates expressed toxin genes at a higher frequency, which are adaptive to $S$. epidermidis given that low virulence is positive for its relationship with the host. According to Massey et al. [36], evolution can favor species that cause little or no damage to the host because the infection can persist for a long period of time, favoring transmission from one host to another.

\section{Conclusions}

The present study showed that the clinical CoNS strains tested are reservoirs of enterotoxin genes. The genes are mainly associated with $S$. epidermidis, which carries a regulatory system that allows their expression. The findings on toxigenicity and gene regulation of $S$. epidermidis isolated from blood samples highlight the importance of correct identification of CoNS associated with nosocomial bacteremias in order to improve the accuracy of positive blood culture results and to implement strategies for the treatment and control of infections caused by this microorganism.

\section{Funding}

This work was supported by São Paulo State Research Foundation (FAPESP; grant 2011/23746-2) and National Council for Scientific and Technological Development (CNPq; grant 470649/2011-9).

\section{Author contributions}

Valéria Pereira: Conceived and designed the study, performed the microbiological tests, developed the molecular techniques, analyzed the data, and wrote the article.

Luiza Pinheiro: Participated in the identification and detection of enterotoxin genes.

Katheryne Martins: Participated in RNA extraction.

Adilson Oliveira: Participated in RNA extraction.

Danilo Riboli: Participated in the PFGE analysis.

Maria de Lourdes da Cunha: Responsible for the conception and design of the study, coordination of laboratory work, data analysis, and manuscript writing. All authors read and approved the final version of the manuscript.

\section{Conflicts of interest}

The authors declare that they have no competing interests.

\section{Acknowledgments}

São Paulo State Research Foundation and National Council for Scientific and Technological Development.

\section{References}

[1] B.W.E. Kloos, T L, Staphylococcus and Micrococcus, in: Y.P.R. Murray, E.J. Baron, M.A. Pfaller, F.C. Tenover, R.H. (Org) (Eds.), Man. Clin. Microbiol, $6^{\circ}$ ed, American Society Microbiology, Washington, 1999, pp. 264-282.

[2] M.C. Rowlinson, P. LeBourgeois, K. Ward, Y. Song, S.M. Finegold, D. a. Bruckner, Isolation of a strictly anaerobic strain of Staphylococcus epidermidis, J. Clin. Microbiol. 44 (2006) 857-860, http://dx.doi.org/10.1128/JCM.44.3.857-860. 2006.

[3] E. a Grice, J. a Segre, The skin microbiome, Nat. Rev. Microbiol. 9 (2011) 244-253, http://dx.doi.org/10.1038/nrmicro2619.

[4] M. Otto, Virulence factors of the coagulase-negative staphylococci, Front. Biosci. 9 (2004) 841, http://dx.doi.org/10.2741/1295.

[5] P. Marrack, J. Kappler, The staphylococcal enterotoxins and their relatives, Sci. (80-. ) 248 (1990) 1066, http://dx.doi.org/10.1126/science.2343314.

[6] R.P. Novick, E. Geisinger, Quorum sensing in staphylococci, Annu. Rev. Genet. 42 (2008) 541-564, http://dx.doi.org/10.1146/annurev.genet.42.110807.091640.

[7] J.A. McCulloch, Avaliação da funcionalidade do locus acessory gene regulator (agr) em cepas de Staphylococcus aureus brasileiras com suscetibilidade reduzida aos glicopeptídeos, (2006) http://www.teses.usp.br/teses/disponiveis/9/9136/tde04042007-153429/pt-br.php.

[8] R.P. Novick, D. Jiang, The staphylococcal saeRS system coordinates environmental signals with agr quorum sensing, Microbiology 149 (2003) 2709-2717, http://dx. doi.org/10.1099/mic.0.26575-0.

[9] W.E.W. Koneman, S.D. Allen, W.M. Janda, P.C. Schreckenberger, W. C., Color Atlas and Textbook of Diagnostic Microbiology, $5^{\circ}$ ed, (1997) Lippincott, Philadelphia.

[10] M.L.R.S. Cunha, Y.K. Sinzato, L.V. A Silveira, Comparison of methods for the identification of coagulase-negative staphylococci, Mem. Inst. Oswaldo Cruz 99 (2004) 855-860 S0074-02762004000800012.

[11] I. Couto, S. Pereira, M. Miragaia, I. Santos Sanches, H. De Lencastre, Identification 
of clinical staphylococcal isolates from humans by internal transcribed spacer PCR, J. Clin. Microbiol. 39 (2001) 3099-3103, http://dx.doi.org/10.1128/JCM.39.9. 3099-3103.2001.

[12] M. Li, M. Guan, X.F. Jiang, F.Y. Yuan, M. Xu, W.Z. Zhang, Y. Lu, Genetic polymorphism of the accessory gene regulator (agr) locus in Staphylococcus epidermidis and its association with pathogenicity, J. Med. Microbiol. 53 (2004) 545-549, http://dx.doi.org/10.1099/jmm.0.05406-0.

[13] L.K. McDougal, C.D. Steward, G.E. Killgore, J.M. Chaitram, S.K. McAllister, F.C. Tenover, Pulsed-field gel electrophoresis typing of oxacillin-resistant Staphylococcus aureus isolates from the United States: establishing a national database, J. Clin. Microbiol. 41 (2003) 5113-5120, http://dx.doi.org/10.1128/JCM.41. $11.5113-5120.2003$.

[14] S.M. Hudome, M.C. Fisher, Nosocomial infections in the neonatal intensive care unit, Curr. Opin. Infect. Dis. 14 (2001) 303-307, http://dx.doi.org/10.1097/ 00001432-200106000-00010.

[15] K.L. Rogers, P.D. Fey, M.E. Rupp, Coagulase-negative staphylococcal infections, Infect. Dis. Clin. North Am. 23 (2009) 73-98, http://dx.doi.org/10.1016/j.idc. 2008.10.001.

[16] F. Takeuchi, F. Takeuchi, S. Watanabe, S. Watanabe, T. Baba, T. Baba, H. Yuzawa, H. Yuzawa, Y. Morimoto, Y. Morimoto, M. Kuroda, M. Kuroda, M. Takahashi, M. Takahashi, A. Ankai, A. Ankai, S. Baba, S. Baba, S. Fukui, S. Fukui, J.C. Lee, J.C. Lee, K. Hiramatsu, K. Hiramatsu, Whole-genome sequencing of, Society 187 (2005) 7292-7308, http://dx.doi.org/10.1128/JB.187.21.7292.

[17] F. Chaves, M. García-Alvarez, F. Sanz, C. Alba, J.R. Otero, Nosocomial spread of a Staphylococcus hominis subsp. novobiosepticus strain causing sepsis in a neonatal intensive care unit, J. Clin. Microbiol. 43 (2005) 4877-4879, http://dx.doi.org/10. 1128/JCM.43.9.4877-4879.2005.

[18] N. Farrag, Staphylococcus lugdunensis endocarditis, Postgrad. Med. J. 77 (2001) 259-260, http://dx.doi.org/10.1136/pmj.77.906.259.

[19] T. Alves De Paula, P. Souto, L. Da Silva, L. Gustavo, S. Berriel, R. De Caso, D. Polyana, S. Lopes, D. Silva, Endocardite infecciosa por Staphylococcus capitis em valva nativa. Relato de caso. Infective endocarditis by Staphylococcus capitis in native valve. Case report, ([s.d.]).

[20] G.D. Kini, K. Patel, A.R. Parris, J.S. Tang, An unusual presentation of endocarditis caused by Staphylococcus warneri, Open Microbiol. J. 4 (2010) 103-105, http://dx. doi.org/10.2174/1874285801004010103.

[21] M.L.R.S. Cunha, E. Peresi, R.A.O. Calsolari, J.P. Araújo Júnior, Detection of enterotoxins genes in coagulase-negative staphylococci isolated from foods, Braz. J. Microbiol. 37 (2006) 381-390, http://dx.doi.org/10.1590/S151783822006000100013.

[22] N.G. Vasconcelos, V.C. Pereira, J.P. Araújo Júnior, M.D.L.R.S. da Cunha, Molecular detection of enterotoxins E, G, H and I in Staphylococcus aureus and coagulase-negative staphylococci isolated from clinical samples of newborns in Brazil, J. Appl. Microbiol. 111 (2011) 749-762, http://dx.doi.org/10.1111/j.1365-2672.2011. 05076.x.

[23] R.A. de Oliveira Calsolari, V.C. Pereira, J.P. Araújo Júnior, M. de L.R. de Souza da Cunha, Determination of toxigenic capacity by reverse transcription polymerase chain reaction in coagulase-negative staphylococci and Staphylococcus aureus isolated from newborns in Brazil, Microbiol. Immunol. 55 (2011) 394-407, http://dx doi.org/10.1111/j.1348-0421.2011.00336.x.

[24] D.W. Borst, M.J. Betley, Phage-associated differences in staphylococcal enterotoxin A gene (sea) expression correlate with sea allele class, Infect. Immun. 62 (1994) 113-118 http://iai.asm.org/cgi/content/long/62/1/113.

[25] N. Balaban, A. Rasooly, Staphylococcal enterotoxins, Int. J. Food Microbiol. 61 (2000) 1-10, http://dx.doi.org/10.1016/S0168-1605(00)00377-9.

[26] J.C. Marr, J.D. Lyon, J.R. Roberson, M. Lupher, W.C. Davis, G.A. Bohach, Characterization of novel type $C$ staphylococcal enterotoxins: biological and evolutionary implications, Infect. Immun. 61 (1993) 4254-4262.

[27] S. Jarraud, M.A. Peyrat, A. Lim, A. Tristan, M. Bes, C. Mougel, J. Etienne, F. Vandenesch, M. Bonneville, G. Lina, egc, a highly prevalent operon of enterotoxin gene, forms a putative nursery of superantigens in Staphylococcus aureus, J. Immunol. 166 (2001) 669-677, http://dx.doi.org/10.4049/jimmunol.166.1.669.

[28] A.K. Varshney, J.R. Mediavilla, N. Robiou, A. Guh, X. Wang, P. Gialanella, M.H. Levi, B.N. Kreiswirth, B.C. Fries, Diverse enterotoxin gene profiles among clonal complexes of Staphylococcus aureus isolates from the Bronx, New York, Appl. Environ. Microbiol. 75 (2009) 6839-6849, http://dx.doi.org/10.1128/AEM. 00272-09.

[29] P. Dufour, S. Jarraud, F. Vandenesch, R.P. Novick, M. Bes, G. Lina, J. Etienne, High genetic variability of the agr locus in Staphylococcus species high genetic variability of the agr locus in Staphylococcus species, J. Bacteriol. 184 (2002) 1180-1186, http://dx.doi.org/10.1128/JB.184.4.1180.

[30] M.T. Tremaine, D.K. Brockman, M.J. Betley, Staphylococcal enterotoxin A gene (sea) expression is not affected by the accessory gene regulator (agr), Infect. Immun 61 (1993) 356-359 http://www.ncbi.nlm.nih.gov/pubmed/7678101.

[31] L.B. Regassa, J.L. Couch, M.J. Betley, Steady-state staphylococcal enterotoxin type $\mathrm{C}$ mRNA is affected by a product of the accessory gene regulator (agr) and by glucose, Infect. Immun. 59 (1991) 955-962 http://www.ncbi.nlm.nih.gov/ pubmed/1997441.

[32] S.M.K. Schoenfelder, C. Lange, M. Eckart, S. Hennig, S. Kozytska, W. Ziebuhr, Success through diversity - how Staphylococcus epidermidis establishes as a nosocomial pathogen, Int. J. Med. Microbiol. 300 (2010) 380-386, http://dx.doi.org/ 10.1016/j.ijmm.2010.04.011.

[33] T. Bremell, A. Tarkowski, Preferential induction of septic arthritis and mortality by superantigen-producing staphylococci, Infect. Immun. 63 (1995) 4185-4187 http://www.ncbi.nlm.nih.gov/pubmed/7558340.

[34] A. Tarkowski, H. Wagner, Arthritis and sepsis caused by Staphylococcus aureus: can the tissue injury be reduced by modulating the host's immune system? Mol. Med. Today 4 (1998) 15-18, http://dx.doi.org/10.1016/S1357-4310(97)80540-0.

[35] A.F. Michelin, I.Z. Carlos, Interação das enterotoxinas estafilocócicas com o sistema imune do hospedeiro, Scopus (2004) 83-95.

[36] R.C. Massey, M.J. Horsburgh, G. Lina, M. Höök, M. Recker, The evolution and maintenance of virulence in Staphylococcus aureus: a role for host-to-host transmission? Nat. Rev. Microbiol. 4 (2006) 953-958, http://dx.doi.org/10.1038/ nrmicro1551. 